\title{
THE LIMA BEAN POD-BORER CATERPILLARS OF PUERTO RICO
}

\author{
By George N. Wolcont, Entomologist, \\ Insular Experiment Station, Río Piedras, Puerto Rico.
}

The three species of pod-boring caterpillars which attack lima beans in Puerto Rico constitute the greatest obstacle to the profitable production of this crop. Thus, an economic study of these caterpillars has been one of the main entomological projects at the Isabela Sub-Station ever since lima beans were planted there. Careful and detailed observations were made there on beans planted in the late spring of 1931, to determine the relative abundance of the caterpillars in different varieties of beans. $O n$ beans planted in the fall of 1931, comparable observations were made on their relative abundance in fields sprayed with Bordeaux mixture and magnesium arsenate, and in fields that were not sprayed at all. On beans planted in the spring of 1932, observations were made on sprayed and unsprayed beans, and on proximity to alternate hosts of the caterpillars. In an extension of this spraying and altemate host experiment, to which was added treatments with nicotine and pyrethrum, on beans planted late in the fall of 1932, final results have just been obtained. As the net result of these observations and experiments, it can now be definitely stated that no method of control of these pests is known. Indeed, all those suggested as likely to result in at least partial control are found by experiment to be valueless. Before con. sidering the experimental evidence in detail, however, it may be desirable to give a general discussion of the insects, and especially of distinguishing characters of the three species of caterpillars and their habits as affecting the possibility of control by any of the means at present in common use.

The term "pod-borer" refers to the habit of these caterpillars of entering the pod when they are very small, and thereafter feeding entirely within the pod, remaining there thruout their larval existence, and sometimes pupating there. The female moths lay their eggs singly on the flower sprays, and the young caterpillars on hatching feed on any of the floral parts. Many of the buds which drop, some of the flowers which drop without setting pods, and most of the young pods which drop, fall from the vine because they have been more or less injured by the feeding of these small caterpillars. The 
initial losses caused by these caterpillars are especially obvious at the beginning of the crop, when the ground under the vines will be strewn with buds, flowers and young pods which have served as food for the young: caterpillars.

When the pods get to be a little larger and firmer, however, they do not fall from the vine when one of these caterpillars begins to feed, but are thick enough so that the caterpillar burrows right up inside of the pod. As the caterpillar continues to feed inside, and the pod continues to grow, a callus is formed where the caterpillar burrowed in, effectively closing and entirely concealing the point of entrance. So far as one ean see by looking at the outside, the pod is perfect. Yet actually the caterpillar continues to feed inside, sometimes confining its activities to only one bean, altho often it chews into two or even three. While the caterpillar is still actively feeding and growing, ordinarily there is no external indication of its presence, but by the time that it approaches full size, its excrement has begun to rot and show thru the pod walls. Thus the infested pod is ruined from the standpoint of marketing, and is discarded when the beans are being sorted for shipment.

All of these injuries mentioned tend to reduce the total production. Quality is also affected, however, when pods ready for shipment contain small caterpillars, for these caterpillars continue to feed and grow while the beans are en route to market. Even if their presence is not apparent when the green beans are sold, the ultimate consumer preparing the beans for cooking is disgusted to discover that they are wormy, and is prejudiced against buying green lima beans in the pod again. Of course no one individual caterpillar can possibly cause all of these described types of injury, but different individuals of each kind of caterpillar eause each one of all these types of injury.

From the standpoint of extensive distribution and of quarantine restrictions at present in force, Maruca testulalis Geyer, a Pyralid. Pyraustinid caterpillar, is of the greatest importance. It is present in Japan and many other regions of the old world, but only in Cuba and Puerto Rico of the new world, and specifically not in the United States. For that reason, since July 1, 1925, no beans in the pod can be exported from the West Indies to the United States, except during the winter, and only under special permit and inspection, thus to a considerable extent limiting production in the West Indies. Incidentally, these restriction have been responsible for an intensive study of this insect in Cuba, where it is the most common pod-boring caterpillar. In Puerto Rico, Maruca is of only minor importance, 
not because it is less abundant than in Cuba, but because two other species are so much more abundant and cause much heavier losses.

All the general statements made regarding pod-borer caterpillars do not apply exactly to Maruca, for the caterpillars after burxowing into the pod, have the habit of keeping an exit open to the outside, thru which to void their excrement. This habit is also of value to the bean grower, for he is thus able to make sure of all infested pods, and eliminate them as culls when green beans are being prepared for shipment for distant markets. Of course it does not lessen the injury caused by the caterpillars, but at least the shipper can be sure that

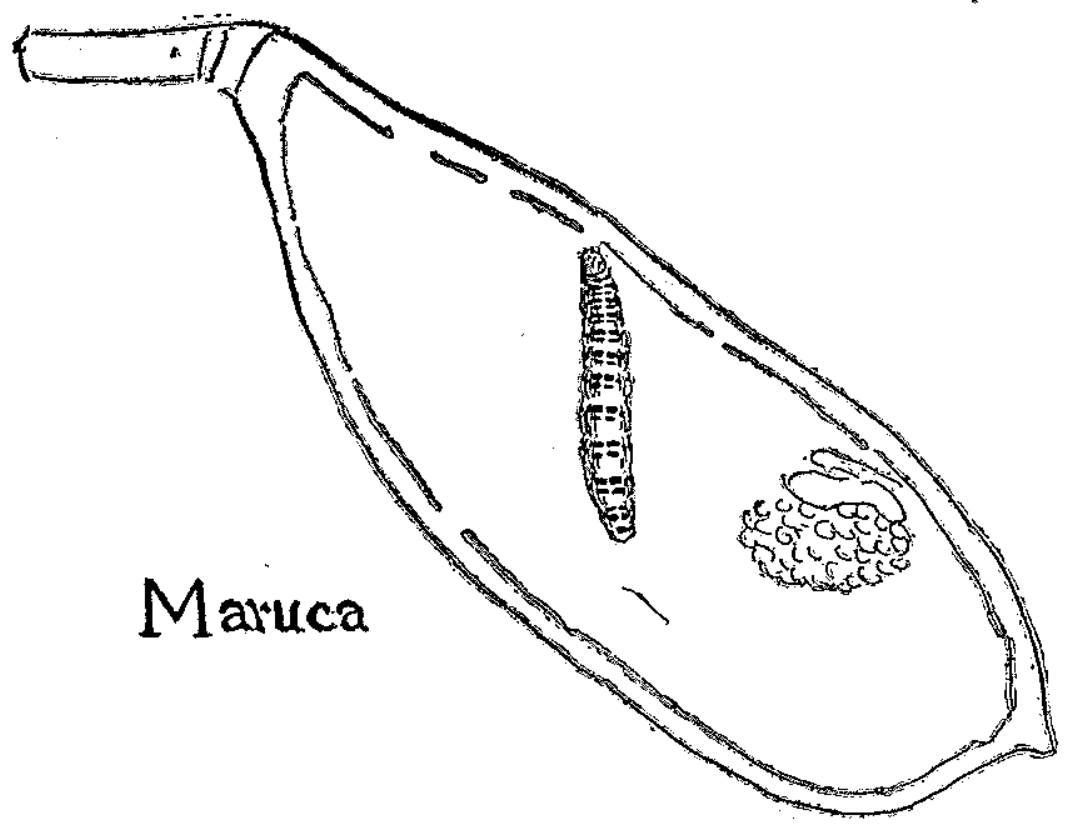

FIG. 1. Caterpillar of Maruca testulalis Geyer in small pod in which it has eaten all the beans. About twice natural size. (Original).

he is not sending out infested pods which will rot en route, or arrive in the kitehen of the housewife wormy and disgusting.

Maruca caterpillars are generally of a creamy white, and can most readily be distinguished by their spotted appearance, for they have four large black or dark grey spots on the back of nearly every segment. Sometimes the spots are not very dark, but usually they are quite distinct, and coupled with the presence of a frass-disposal hole to the outside of the pod, one can usually identify the caterpillar without difficulty. When fully grown, the caterpillars are two-thirds 
of an inch long, and are then about to leave the pod where they have been feeding. They spin cocoons almost anywhere outside of the pod, or at times, even inside a dry pod, but usually their cocoons are found between pods, or on bean hampers, or in trash on the ground, and only rarely at any great depth in the ground itself. The moth is very active, and when not flying about, stands with wings outspread and all ready to go. The forewings are chocolate brown, with a large, white triangular spot on the front margin, and the hind wings are silvery white with a brown spot at the corner more distant from the body.

Parasites of the caterpillar have been reared in Cuba, but are not abundant, and are a very minor factor in checking the numbers

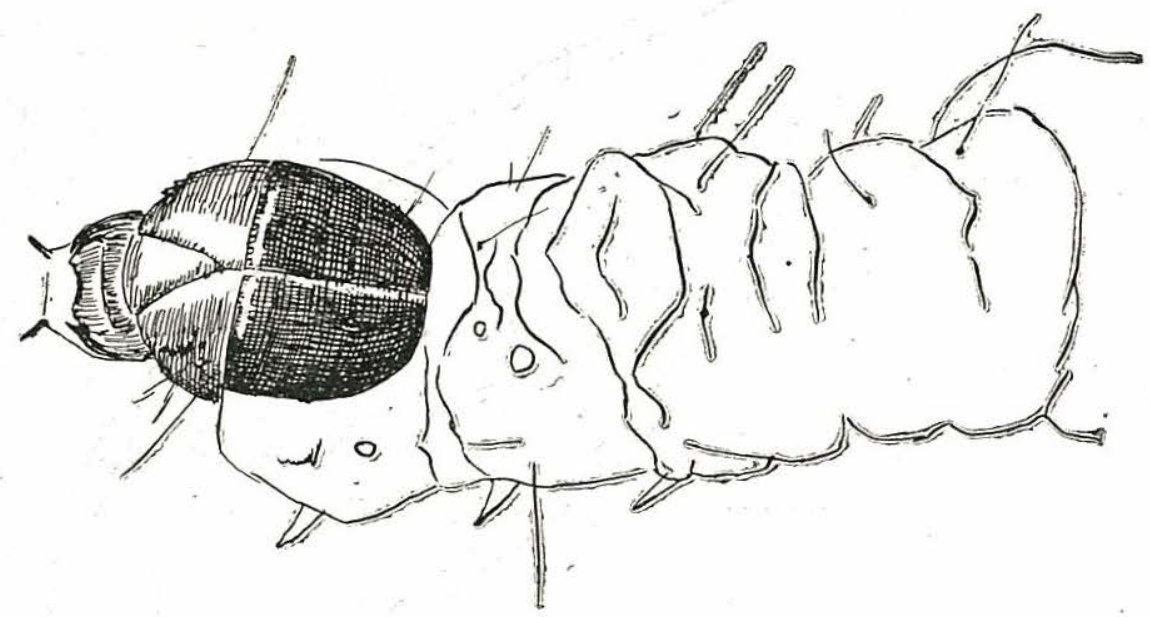

Fig. 2. Head and fore part of body of the caterpillar of Fundella cistipennis Dyar. About twenty times natural size. (Original).

of the pest. Spraying with Bordeaux has no effect on the amount of infestation, and about all that growers can do is to hand kill all the caterpillars that crawl out of the pods while they are being packed for shipment, and to destroy the culls. Experiments in Cuba have shown that the caterpillars in the pods can be killed by maintaining the pods for an hour in moist atmosphere of $44^{\circ}$ to $46^{\circ} \mathrm{C}$., or by fumigating with carbon bisulfid for two or three hours. By such means, wormy beans may be prepared to meet quarantine restrictions, and shipped to northern markets if a temporary scarcity of fresh beans warrants. From the standpoint of maintaining standards, however, a more careful inspection and culling out of all worm-in. 
fested pods is much more satisfactory, even tho in special instances it may not be so immediately profitable.

The two more abundant species of pod-boring caterpillars in Puerto Rico are: Etiella zinckenella Treitschke (known in California as E. schisticolor Zeller) and Fundella cistipennis Dyar. Both insects belong to the same sub-family of the Pyralidae: Phycitinae, and in their larval stage are almost indistinguishable. Yet obvious differences do exist, and in Puerto Rico one caterpillar attacks lima beans only during the winter time, when they are being shipped to northern markets, while the other occurs in abundance only during the spring, summer and fall, when no shipments can be made on account of quarantine restrictions, and thus from the standpoint of the export grower is not an economic pest at all. In their earlier

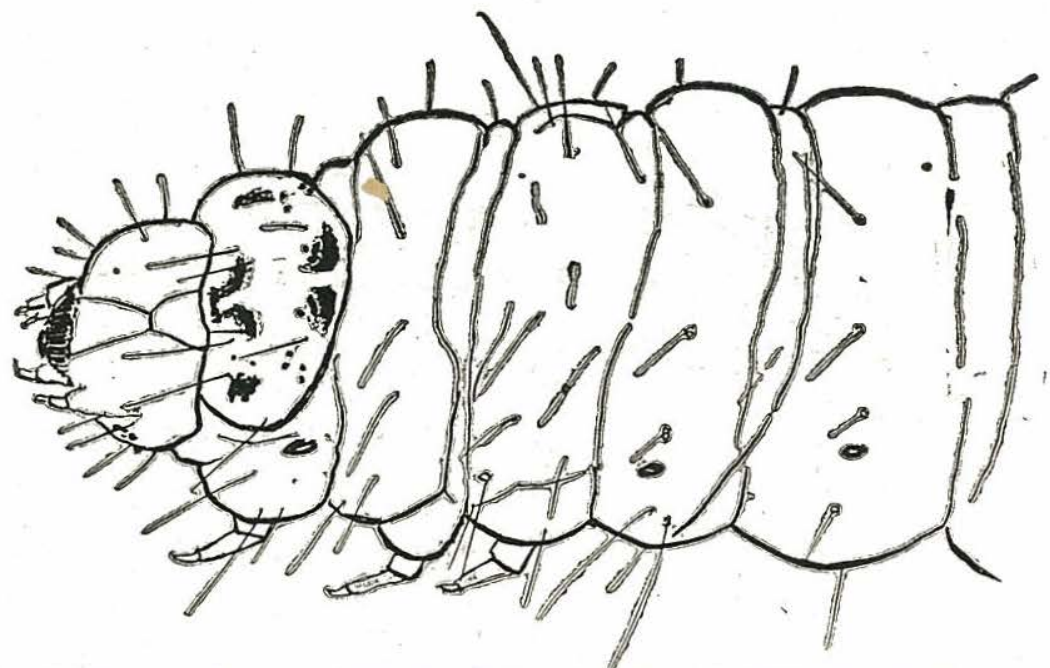

FIG. 3. Head and fore part of body of the caterpillar of Etiella zinclienella Treit., showing pattern on thoracic shield. About twenty times natural size. (Original).

instars, the eaterpillars are indistinguishable by any gross structure, color or marking, both being light green in color, with a dark brown or black head and thoracic shield. In the last instar, many of the caterpillars as they approach full size become purplish above, altho others (of both species) become more yellowish and creamily opalescent. Both are cylindrical in shape and in size approach Maruca, two-thirds of an inch long.

Their heads (in both species) vary in depth of coloration from a light yellow to a dark brown, but the thoracic shield, just back of the 
head, furnishes the clue to specific identification. The thoracic shield of Fundella cistipennis is of the same color as the head, or possibly a little darker, ummarked, or with the markings scarcely visible because of the dark color of the entire shield, or with the markings distinct but vaguely outlined and of a variable pattern. By contrast, the thoracic shield of Etiella zinckcnella is invariably opalescent greenish-yellow, marked with a very definite pattern in black; two confluent crescents in the center forward, two broader ones to the rear, and a mark on each side, together with several pairs of small black spots, the four larger anterior marks being in sharply seulptured depressions. This sounds complicated, but, in practise, after one has seen both kinds of caterpillars at the same time and made the comparison, the difference is thereafter unmistakable.

Under normal conditions, the tough, grey cocoons of both species of caterpillars are made at a considerable depth in the soil, those of Etiella at a considerably greatex depth than those of Fundella, but not in hampers or in trash in the surface of the ground as are those of Maruca. Adults emerge within a couple of weelis.

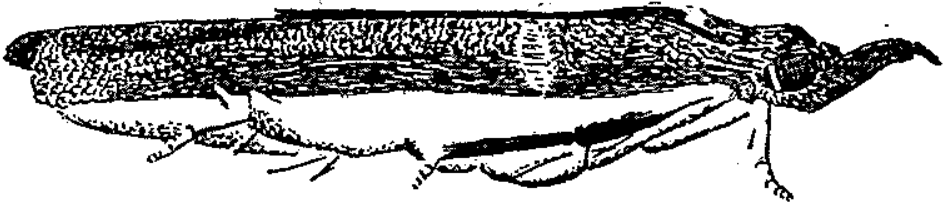

Fig. 4. Moth of Etiella zinclenella Treit. About eiglt times natural size. (Original).

The adult moths of both species when at rest keep their wings tightly folded around their abdomen, very different from the outspread wings of Maruca, apparently always just about to fly away. Otherwise than in the manner of holding their wings while at rest, the two species are not similar in appearance, for the forewings of Etiella are broadly margined with silvery white, these margins blending with the white of the legs and abdomen when the moth is at rest. Its large palpi stick out like a beak in front. The moth of Fundella cistipennis is of a characterless, inconspicuous greyish-brown, with no marked or well-defined pattern on the wings, but with the interesting habit of often keeping the ends of its antennae underneath its folded wings.

As regards other hosts than lima beans, the months show a most surprising difference in those on which they oviposit. During warm weather, Etiella caterpillars, somewhat dwarfed and dried-up in ap- 
pearance as compared with the plump, juicy larvae occurring in lima beans, and longitudinally striped with purple, are quite common in the pods of Crotalaria incana, and in no other species of this gemus of plant. Observations on this selection of host plant were made independently by two entomologists in Cuba (L. Dean Christenson \& S. C. Bruner), and are confirmed by observations made by the writer in Puerto Rico. On the beach at Mameyes, Everx mature pod of several bushes of Crotalaria incana, observed in mid-summer, was infested. Thruout the year, Fundella caterpillars are to be found attacking the pods of sword beans and beach beans, Canavalia ensiformis and $C$. maritima, often causing much more obvious external injuries than they do to the pods of lima beans. Sometimes as many as 3 or 4 caterpillars may occur in a single pod. (See plate XIX). (Maruca caterpillars are also often found in sword bean pods, their abundance in this host in Puerto Rico considerably

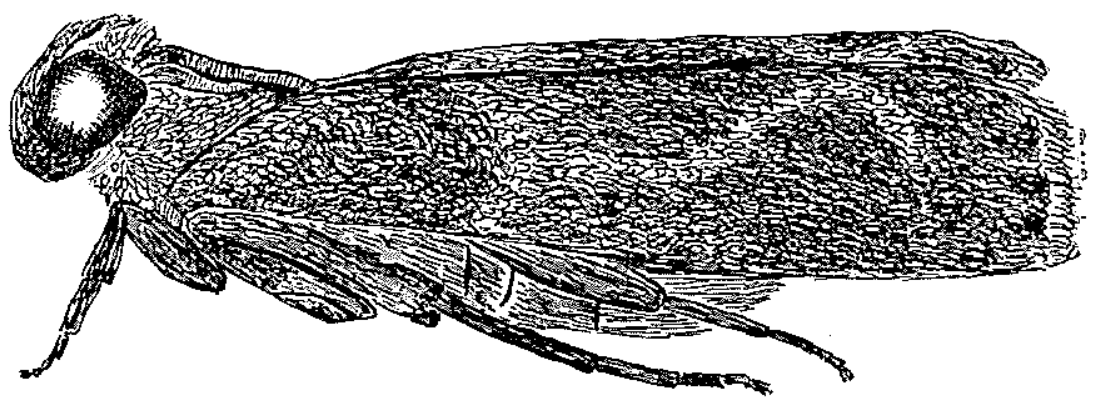

F1G. 5. Moth of Fundella cistipennis Dyar. Abont ten times natural size. (Original).

exceeding that in lima beans). Fundella caterpillars also burrow in the stems of cowpeas and attack the young shoots and buds.

The range of these two such similar yet divergent species overlaps only in Puerto Rico, so far as is known. Frundella cistipennis was originally described as Ballovia from Barbados, and has since been found in St. Vincent, St. Croix, Vieques, Puerto Rico and at Port-auPrince, Haiti. Etiella zinckenella is of cosmopolitan distribution, being reported from many European and Asiatic localities, Colombia in South American, and from many places in the United States, altho it is an economic pest only on the Pacific coast. In the West Indies, it occurs only in Cuba and Puerto Rico.

The reported scarcity of Etiella zinckenella on lima beans in Cuba is presumably largely due to the fact that this crop is grown there only for export during the winter. In Puerto Rico, Etiella is equally 
scarce during most of the shipping season, but in experimental plots of beans planted during the late spring, it becomes very abundant, often attacking from a fourth to a third of all mature pods. During the winter, when lima beans in the pod may legally be shipped to the United States, practically no Etiella caterpillars occur, their place being taken by smallers numbers of Fundella, and in lima beans grown at the higher elevations, a few Maruca caterpillars in addition.

The first counts made of pod-borers at Isabela will serve to indicate the prevalence of Etiella in the late spring, altho they were primarily intended to determine the relative infestations of the caterpillars in different varieties of beans. These observations were made in a field planted on Feb. 26, 1931, in which, after the first month, the plants were sprayed every ten days with Bordeaux mixture. The purpose of the planting was to obtain data on yields, but was also available to the writer for examination as to infestation of the pods by caterpillars. The plot was small and samples of each variety of only 25 pods were examined. At the time the examinations were commenced, the characters distinguishing the three kinds of caterpillars were not known, and it is merely presumed that most of the caterpillars observed at first were Etiella zinckenella, as all of them were known to be after the first four observations.

PER CENT OF INFESTATION BY POD-BORER CATERPILLARS

\begin{tabular}{|c|c|c|c|c|c|c|c|c|c|c|c|c|c|c|}
\hline $\begin{array}{l}\text { A verage } \\
\text { of the } \\
\text { variety }\end{array}$ & Variety & 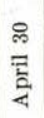 & 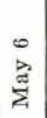 & $\stackrel{\varrho}{\stackrel{一}{\Sigma}}$ & 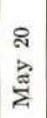 & $\begin{array}{l}\text { a } \\
\stackrel{2}{\Sigma}\end{array}$ & 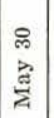 & 告 & $\begin{array}{l}\exists \\
\Xi \\
\Xi \\
\Xi\end{array}$ & 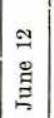 & $\stackrel{9}{9}$ & $\stackrel{\infty}{\grave{\Xi}}$ & 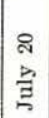 & 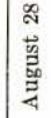 \\
\hline $\begin{aligned} & 12 \ldots \ldots \ldots \\
& 13 \ldots \ldots \\
& 9 \ldots \ldots \\
& 18 \ldots \ldots\end{aligned}$ & 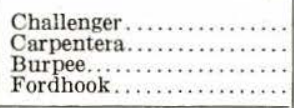 & $\begin{array}{r}8 \\
12 \\
30 \\
44 \\
\end{array}$ & $\begin{array}{r}20 \\
24 \\
4 \\
32 \\
\end{array}$ & $\begin{array}{r}8 \\
20 \\
4 \\
16 \\
\end{array}$ & $\begin{array}{r}16 \\
12 \\
8 \\
8 \\
\end{array}$ & $\begin{array}{l}0 \\
0 \\
0 \\
0\end{array}$ & $\begin{array}{l}\cdots \\
\cdots \\
\cdots \\
\cdots\end{array}$ & $\begin{array}{l}\cdots \\
\cdots \\
\cdots \\
\cdots\end{array}$ & $\begin{array}{c}\cdots \\
\cdots \\
\cdots \\
\cdots\end{array}$ & $\begin{array}{r}8 \\
16\end{array}$ & $\begin{array}{r}24 \\
8 \\
\cdots \\
\cdots \\
\end{array}$ & \begin{tabular}{|c|}
$\mid \cdots$ \\
$\cdots$ \\
$\cdots$ \\
$\cdots$
\end{tabular} & $\begin{array}{l}\cdots \\
\cdots \\
\cdots \\
\cdots\end{array}$ & $\begin{array}{l}\cdots \\
\cdots \\
\cdots\end{array}$ \\
\hline $9 \ldots \ldots$ & A verage....$\ldots \ldots \ldots \ldots$ & 23 & 20 & 12 & 11 & 0 & 3 & 0 & 5 & 12 & 16 & 6 & 15 & 0 \\
\hline
\end{tabular}

On another field of Challenger pole beans planted at about the same time, at Maleza, near the Agujereada light-house, the infestation by Etiella on June 9, 1931 was total, many pods containing two or three caterpillars. By June 30th, it had dropped to 36 per cent infestation, and was 46 per cent on July 20th. In explanation of the great difference in infestation, as compared with the field at Isabela only five or six miles away, it should be stated that infestations are usually very heavy at the beginning of the crop, dropping off rapidly when production is really started.

On the drops from lima beans observed December 1, 1931, in a field of Challenger pole beans at Isabela, sprayed weekly with Bordeaux and magnesium arsenate, the infestation was more than total, 
Etiella caterpillars being fifteen times as numerous as Maruca, and no Fundella caterpillars present. Ten days later, on drops in the same field, most of the caterpillars were Fundella, some were Etiella, and a few Maruca were found. This field did not come into full production until the latter part of December, at which time comparison could be made with two unsprayed fields nearby of the same variety. All of these fields were in commercial production, consequently only cull pods were available for examination.

The cause of rejection varied considerably, being much more numerous in the unsprayed fields on account of spotting by Elsinoe, or injury by the leaf-folder caterpillar, Lamprosema indicata F., both of which were largely controlled in the sprayed field. Thus the frequency of infestation by pod-borers in the culls from the sprayed field appears much higher, altho it might not vary greatly from the unsprayed fields if the total crop could be sampled. Whenever possible, samples of 100 or 200 pods were examined. The records are given in the following table.

INFESTATION OF POD-BORER OATERPILLARS IN LIMA BEANS GROWN AT ISABELA, WINTER OF 1931-32

\begin{tabular}{|c|c|c|c|c|c|c|}
\hline Date & Condition & Fundella & Etiella & Maruca & $\begin{array}{l}\text { Caterpillar } \\
\text { gone (or } \\
\text { too small } \\
\text { to identify) }\end{array}$ & Total \\
\hline December $24 \ldots \ldots \ldots$ & Sprayed........... & 34 & 12 & 1 & & 47 \\
\hline December $31 \ldots . . .$. & Unsprayed............ & 14 & & 1 & 10 & 25 \\
\hline December $31 \ldots . . .$. & Sprayed............. & 14 & 2 & 2 & 13 & 31 \\
\hline January $6 \ldots \ldots \ldots$ & Unsprayed......... & 16 & & & 24 & 40 \\
\hline January $6 \ldots \ldots \ldots$ & Sprayed........... & 35 & & 1 & 12 & 48 \\
\hline January $13 \ldots \ldots \ldots$ & Unsprayed.......... & 5 & a & ......... & 20 & 25 \\
\hline January $13 \ldots \ldots \ldots$ & Sprayed............. & 9 & . $\ldots \ldots \ldots$ & ......... & 7 & 16 \\
\hline January $20 \ldots \ldots \ldots$ & Unsprayed......... & 1 & (........... & [......, & 6 & 7 \\
\hline January $20 \ldots \ldots \ldots$ & Sprayed....... & 1 & ( $\ldots \ldots \ldots \ldots \ldots$ & ( & 6 & 7 \\
\hline January $28 \ldots \ldots \ldots$ & Unsprayed.......... & $\hat{1}$ & 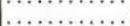 & & 7 & 8 \\
\hline January $28 \ldots . . . .$. & Sprayed....... & 1 & {$[\ldots \ldots \ldots$} & …...... & 6 & 7 \\
\hline February $3 \ldots \ldots \ldots$ & Unsprayed......... & 16 & & & & 16 \\
\hline February $3 . \ldots \ldots \ldots$ & sprayed .............. & 45 & $\mid \begin{array}{l}\cdots \\
\cdots\end{array} \ldots \ldots \ldots \ldots$ & (........... & & 45 \\
\hline February $3 \ldots \ldots \ldots$ & Unsprayed......... & 9 & .......... & & & 9 \\
\hline February $10 \ldots \ldots$ & Sprayed............ & 18 & ............ & & 37 & 55 \\
\hline February $10 \ldots \ldots$ & Unsprayed........... & 2 & $\mid \begin{array}{l}\cdots \\
\cdots\end{array} \ldots \ldots \ldots \ldots$ & (........... & 6 & 8 \\
\hline February $17 . . . . . .$. & Sprayed............ & 12 & ......... & 2 & 30 & 44 \\
\hline February $17 \ldots \ldots$ & Unsprayed.......... & 1 & & 1 & 1 & 3 \\
\hline February $24 \ldots \ldots \ldots$ & Sprayed........... & 16 & & 2 & 26 & 44 \\
\hline February $24 \ldots \ldots$ & Unsprayed......... & 4 & & . …… & 7 & 11 \\
\hline March $2 \ldots \ldots \ldots \ldots$ & Sprayed............ & 1 & $i$ & ......... & 8 & 10 \\
\hline March $2 \ldots \ldots \ldots \ldots$ & Unsprayed.......... & 1 & & & 3 & 4 \\
\hline March $9 \ldots . . . \ldots . .$. & Sprayed............. & 13 & 1 & $i$ & 25 & 40 \\
\hline March $9 \ldots \ldots \ldots \ldots$ & Unsprayed......... & & & 1 & 5 & 6 \\
\hline March $16 \ldots \ldots \ldots \ldots$ & Sprayed............. & 6 & & 4 & 18 & 28 \\
\hline March $16 \ldots \ldots \ldots \ldots$ & Unsprayed......... & & & & 6 & 6 \\
\hline March $23 \ldots \ldots \ldots \ldots$ & Sprayed............. & 3 & & 7 & 25 & 35 \\
\hline March $23 \ldots . . . \ldots \ldots$ & Unsprayed........ & 4 & & & 5 & 10 \\
\hline March $23 \ldots \ldots \ldots \ldots$ & Unsprayed......... & 2 & 1 & 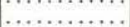 & 5 & 8 \\
\hline March $31 \ldots . . . \ldots . .$. & Sprayed............... & 3 & 2 & ……, & 17 & 22 \\
\hline March $31 \ldots \ldots \ldots$ & Unsprayed......... & 5 & 4 & .......... & 3 & 12 \\
\hline April $6 \ldots . . . . . . . .$. & Sprayed............... & 7 & & , & 21 . & 28 \\
\hline April $6 \ldots . . . . . .$. & Unsprayed............ & 2 & 4 & $\ldots \ldots \ldots \ldots$ & 13 & 19 \\
\hline May $5 \ldots . . . . . . .$. & Sprayed.............. & ........... & 1 & ............... & 7 & 8 \\
\hline May $10 \ldots \ldots \ldots \ldots$ & 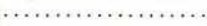 & n........... & 2 & n........... & 4 & 6 \\
\hline Total......... & & 301 & 31 & 23 & & Average 21 \\
\hline
\end{tabular}


The absolute disappearance of Etiella during January and February is well shown in the above record of counts, and its scarcity during March. During the entire period, not a tenth as many Etiella caterpillars were noted as of Fundella, and Maruca was even less abundant. The average infestation appears considerably higher during the winter than in the spring, but it must be remembered that only culls were examined during the winter, while representative samples were available for examination from the previously observed late spring erop.

A part of one unsprayed field observed during the winter had sword beans interplanted between every five rows of lima beans, and a row of Crotalaria incana along one side. The Crotalaria did not begin to have pods until early in March, consequently no observations could be made on whether the insect passed the winter months on this (supposedly) preferred host, rather than on lima beans. No caterpillars were noted in these pods until the latter part of March, when lima beans were also beginning to be infested. On March 24th, several hundred Crotaloria incana pods were available for examination, of which only 2 or 3 per cent were infested by Etiella. On April 5 th, 200 pocis were examined and 15 per cent were found to be infested. In only a few cases were eaterpillars present, but the indications of their former presence were unmistakable, a webbing together of the seeds, quite different from the clean injury caused by the larvae of Utethesia ornatrix. The Etiella caterpillars in Crotalaria have quite a different appearance from those which have fed on lima beans, having a shrunken, shriveled look, are more bluish-gxeen in color and invariably have four longitudinal purplish-chestnut stripes running along the back. On May 12th, 444 pods were available for examination, and of these 18.5 per cent were, or had been, infested by Etiella caterpillars.

The sword beans also, altho planted at the same time, did not begin to come into production until several weeks after the lima beans were bearing heavily, and were as heavily infested by Fundella caterpillars as were the lima beans. Indeed, at no time were many sword beans attacked by either Fundella or Maruca, and, reviewing the observations now, it becomes apparent that sword beans can be of little value in attracting the moths away from the lima beans unless planted several weeks or a month in advance. Heavy infestations of these caterpillars in sword beans have been observed to occur only when the sword beans came into production at about the time the adjacent lima beans ceased to have many pods.

Out of all the hundreds of caterpillars collected, only one Fundella 
was observed to be parasitized. It bore four globular, semi-transparent, greenish maggots attached to one side, which increased rapidly in size, becoming fully grown on the day after the drawing (See Fig. 6) was made, spinning cocoons of grey silk by the next day, and appearing as ant-like adults ten days later. These wasps were identified by $\mathrm{Mr}$. A. B. Gahan as Perisieriola sp., probably cellularis (Say).

As explained in a previous paragraph, the lima beans examined during the winter of 1931-32 were only culls. From such inspections it was impossible to determine whether spraying with Bordeaux and magnesium arsenate had any effect on the pod-boring caterpillars, or not. From a casual inspection of the returns, it would seem the caterpillars were more abundant in the sprayed beans, and it appeared possible this might not be merely the appearance, but the reality. Spraying might cause the small caterpillars to burrow into the pods earlier than they otherwise do normally, thus actually de-

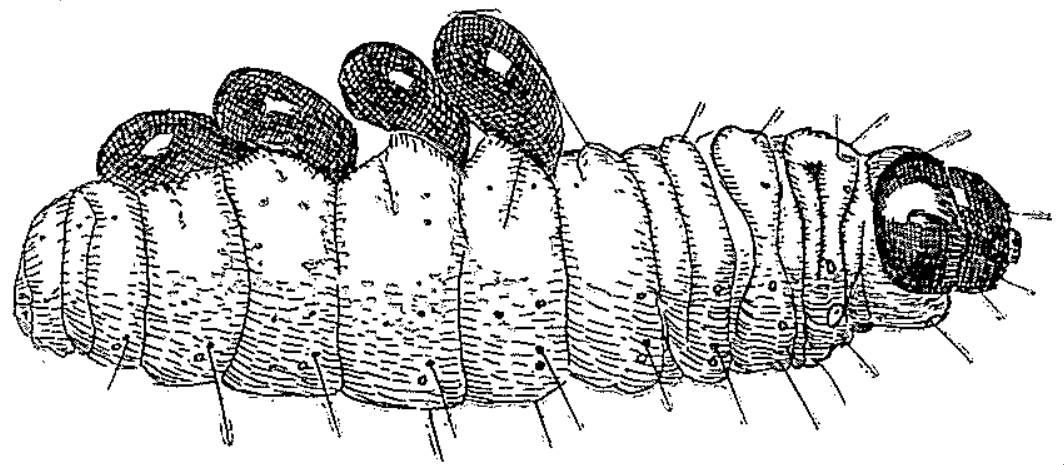

FIG. 6. Caterpillar of Fundella cistipennis Dyar parasitized by maggots of Perisierola prob. cellularis (Say). Alsout fifteen times natural size. (Original).

creasing the number of deaths due to predators and other accidents befalling them while feeding outside of the bean tissue. To more definitely determine the value, or otherwise, of spraying, a specific experiment was conducted during the late spring of 1932. The plan of this experiment was as follows:

1. Crotalaria incana (1 row)

2. Canavalia ensiformis (2 rows)

3. Lima beans-untreated ( 3 rows)

4. Sprayed weekly with Bordeaux mixture, 2-2-50 and Magnesium Arsenate (3 rows)

5. Sprayed weekly with Bordeaux only (3 rows)

6. Check (3 rows)

7. Sprayed with poison only, 2 pounds in 50 gallons water (3 rows) 
8. Check (3 rows)

9. Sprayed with Bordeaux \& poison (3 rows)

10. Check (3 rows)

11. Poison only (3 rows) .

12. Check (3 rows)

13. Bordeaux only (3 rows)

14. Bordeaux \& poison (3 rows)

15. Untreated (3 rows)

16. Canavalia ensiformis (2 rows)

17. Crotalaria incano (1 row)

18. Canavalia ensiformis (3 short rows)

The seed was planted March 3, 1932, and two weeks later both kinds of beans were up, the lima beans having second and third leaves on. The Crotalaria shoots had not ret appeared at this time, and indeed germinated so poorly that, for the purposes of the experiment, their presence may be disregarded. It should be noted that the experiment repeats itself in the reverse order, so that Untreated 3 and 15 are comparable, being beside alternate hosts, while the other untreated rows are true checks, being between sprayed rows. The beans from all comparable treatments were combined for selecting samples for examination, and, so far as possible, these consisted of 100 marketable pods. The first samples were received on June 7 th, the last on July 19th. Neither Maruca nor Fundella caterpillars were found in any beans, all caterpillars being Etiella zinckenella. It should be especially noted that these infestations were not in cull beans, nor in run of the field but, in selected, and apparently marketable beans. The extremely high infestation by Etiella, does not, however, indicatis that this insect is a serious pest of lima beans grown for export to the United States, for these beans were grown during the summer, when no green beans in the pod can be shipped.

SPRAYING EXPERIMENT FOR THE CONTROL OF LIMA BEAN POD-BORER, (ETIELLA ZINCKENELLA TREIT.), SUMMER OF 1932, AT ISABELA, PUERTO R.

\begin{tabular}{|c|c|c|c|c|c|c|c|c|}
\hline A verage & Treatments & June 7 & June 15 & June & 22 & June 29 & July 8 & July 13 \\
\hline & $\begin{array}{l}\text { Untreated, beside sword } \\
\text { beans }\end{array}$ & 40 & 20 & & 24 & 41 & 38 & 25 \\
\hline $40.5 \ldots$ & Untreated check.......... & 49 & 29 & & 35 & 40 & 50 & 1) \\
\hline $31.6 \ldots$ & Sprayed with Poison only. & 37 & 27 & & 32 & 29 & 39 & 26 \\
\hline $36 \ldots$ & $\begin{array}{l}\text { Sprayed wiith Bordeaux } \\
\text { only }\end{array}$ & 44 & 34 & & 27 & 36 & 47 & 29 \\
\hline \multirow[t]{2}{*}{$48 \ldots \ldots$} & $\begin{array}{l}\text { Sprayed with Poison and } \\
\text { Bordeaux }\end{array}$ & 53 & 46 & & 47 & 26 & 66 & 49 \\
\hline & Average Examination.. & 45 & 31 & & 37 & 34 & 48 & 31 \\
\hline
\end{tabular}

Several of the Etiella caterpillars collected in these examinations were parasitized by maggots similar in general appearance to the ones previously observed on the Fundella caterpillar, but in color a dull pinkish. They developed with similar rapidity, but spun tough 
brownish cocoons, the adults emerging ten days later being quite different in appearance. These wasps were identified by Mr. C. F. W. Muesebeck as Heterospilus etiellae Rohwer.

The results of this experiment are not especially convincing, for the presence of Canavalia beside the unsprayed rows could have no possible effect on the infestation of the lima beans by Etiella, as sword bean is not normally a host of this eaterpillar. (It should be mentioned that these sword beans were infested by Fundella caterpillars, even tho none occurred in the lima beans). It would, however, tend to indicate that the less one sprayed, the better, and certainly could be interpreted to mean that any expense for spraying could not be justified on the basis of its value in the control of podborer. The most serious criticism of the experiment, however, is that it deals entirely with the one pod-borer which does not ordinarily affect the beans grown in the winter for export. For practical purposes, the grower is concerned with Fundella, and with Maruca only as an unusual abundance may affect the possibility of meeting quarantine requirements, but with Etiella not at all, because it is not subject to quarantine, and also because it is so scarce in lima beans grown in the winter. Yet this experiment, conducted during the summer, concerned only Etiella.

To meet all of these criticisms, if possible, another experiment was planned, to be conducted during the winter, producing lima beans at the time and under the conditions affecting commercial growers. As one grower, whose statement was quoted and given considerable publicity by one of the companies marketing extracts of pyrethrum, claimed to produce lima beans that had no difficulty in being passed by the quarantine inspectors on account of infestation by pod-borers (whatever that claim might mean), pyrethrum was added to the substances tried. The only possible value for any insecticide in the control of any of these pod-borers would be in killing the eggs or the small caterpillar before it had entered the pod. To kill such minute caterpillars, a contact insecticide might be as valuable as a stomach poison, thus a trial of nicotine sulfate was added to the experiment. The Nicotrol (nicotine sulfate plus penetrol) used was contributed by the Kay Fries Chemicals Inc., and the pyrethrum, in the form of "Pya. grol", by John Powell \& Co., to which firms the writer is thus indebted. The plan of the experiment is as follows:

1. Canavalia ensiformis (3 rows).

2. Untreated (3 rows).

3. Weekly spraying with Bordeaux mixture, 2-2-50 and Magnesium Arsenate, 2 pounds to 50 gallons of mixture (3 rows) 
4. Bordeaux only (3 rows)

5 . Check (3 rows)

6. Bordeaux plus "Nicotrol" (Nicotine Sulfate and "Penetrol") 1 part to 200 of liquid (3 rows)

7. "Pyagrol" (Pyrethrum plus "Penetrol"), 1 part to 200 of water (3 rows)

8. "Pyagrol" (3 rows).

9. Bordeaux plus "Nicotrol" (3 rows).

10. Check (3 rows)

11. Bordeaux only ( 3 rows)

12. Bordeaux \& Magnesium Arsenate (3 rows)

13. Untreated (3 rows)

14. Canavalia ensiformis (3 rows)

Seed was planted on November 18, 1932, and weekly spraying commenced as soon as the first bloom appeared, about two months later. The first samples, 100 pods, unselected, from each series of rows, were received on February 20th, 1933, and as the experiment was being conducted in reversed duplication, were combined to form samples of 200 pods from each treatment. The sixth lot of samples, received March $2 \overline{7}$, consisted of the total production for that week, but was insufficient to make up the total number of the other samples. Production practically ceased for a time thereafter, but the seventh shipment, April 20th, was of the required number. The experiment was conducted in Isabela, but examinations were made at Río Piedras on the day after pieling:

SPRAYKG EXPERIMIENT JN THE ATTEMPTED CONTROL OF THE LIMA BEAN POD-BORER CATERPILLARS: FUNDELLA CISTIPENNIS DYAR. ETIELLA ZINCKENELLA TREIT. MARUCA TEST ULALIS GEYER, CONDUCTED AT ISABELA, PUERTO RICO, WINTER AND SPRING OF 1933

\begin{tabular}{|c|c|c|c|c|c|c|c|c|c|c|}
\hline \multirow[b]{2}{*}{ Dates } & \multicolumn{10}{|c|}{ NUMBER OF Caterpiltars PER 100 PODS (SAMPtES OF 200) } \\
\hline & 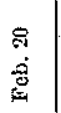 & 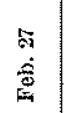 & 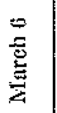 & 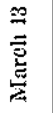 & 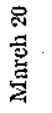 & $\begin{array}{l}\text { 梂 } \\
\text { 总 } \\
\text { 荧 }\end{array}$ & 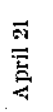 & $\underset{8}{\stackrel{8}{*}}$ & 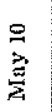 & $\begin{array}{l}\text { 尽 } \\
\text { 䓛 }\end{array}$ \\
\hline 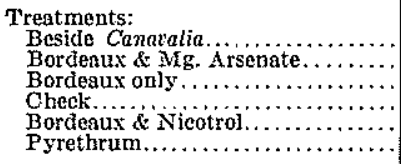 & $\begin{array}{l}2.5 \\
5.0 \\
3.0 \\
3.5 \\
2.5 \\
1.5\end{array}$ & $\begin{array}{r}6.0 \\
4.0 \\
5.0 \\
10.0 \\
4.0 \\
1.5\end{array}$ & $\begin{array}{l}4.0 \\
2.5 \\
2.0 \\
5.0 \\
6.0 \\
5.5\end{array}$ & $\begin{array}{l}2.5 \\
4.5 \\
4.0 \\
4.0 \\
5.0 \\
3.5\end{array}$ & $\begin{array}{l}6.0 \\
4.0 \\
4.0 \\
5.0 \\
3.5 \\
4.5\end{array}$ & $\begin{array}{r}7.1 \\
5.0 \\
6.3 \\
3.7 \\
1.4 \\
3.2\end{array}$ & $\begin{array}{l}3.5 \\
1.0 \\
1.5 \\
4.0 \\
.5 \\
1.5\end{array}$ & $\begin{array}{l}1.5 \\
6.0 \\
3.5 \\
4.5 \\
2.5 \\
3.5\end{array}$ & $\begin{array}{l}9.5 \\
5.5 \\
5.0 \\
4.5 \\
3.5 \\
5.5\end{array}$ & $\begin{array}{r}17.5 \\
10.0 \\
11.0 \\
14.0 \\
8.0 \\
6.5\end{array}$ \\
\hline Average................. & 3.01 & 5.11 & 4.11 & 4. & $4 . \overline{5}$ & 4.5 & 2.0 & 3.6 & 5.6 & 11.3 \\
\hline $\begin{array}{l}\text { Total Caterpillars Identified each } \\
\text { examination: }\end{array}$ & & & & & & & & & & \\
\hline 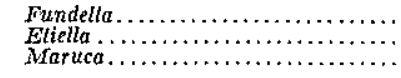 & $\begin{array}{r}19 \\
0 \\
1\end{array}$ & $\begin{array}{r}23 \\
0 \\
4\end{array}$ & $\begin{array}{r}20 \\
1 \\
0\end{array}$ & $\begin{array}{l}7 \\
3 \\
1\end{array}$ & $\begin{array}{r}13 \\
2 \\
0\end{array}$ & $\begin{array}{l}5 \\
2 \\
0\end{array}$ & $\begin{array}{l}3 \\
1 \\
1\end{array}$ & $\begin{array}{l}0 \\
8 \\
1\end{array}$ & $\begin{array}{r}2 \\
16 \\
0\end{array}$ & $\begin{array}{r}6 \\
60 \\
0\end{array}$ \\
\hline
\end{tabular}

The first two examinations appeared to indicate that the eaterpillars were being controlled in the rows sprayed with pyrethrum. 
Most unfortunately, later pickings failed to show any advantage from the use of this extract, and indeed sprays with other substances gave even lower infestations during some later weeks. Of course it is possible that the use of pyrethrum at greater strengths, or oftener, might give complete control, but it is doubtful if such treatments would be commercially practical. Thus the experimental eviclence, to date, indicates no method of control for the lima bean pod-borer caterpillars.

The final experiment, valueless from the control standpoint, is most interesting otherwise in indicating just when Fundella caterpillars cease to be abundant in the spring and their place is taken by much greater numbers of Etiella, fully a month after shipment to the States has been discontinued on account of quarantine restrictions. 